\title{
Floodplain Geomorphology and Response to Hurricanes: Lower Pee Dee Basin, South Carolina
}

\author{
Thomas M. Williams ${ }^{1}$, Bo Song ${ }^{2}$, Daniel Hitchcock ${ }^{2}$, and Thomas L. O’Halloran ${ }^{3}$
}

AUTHORS: ${ }^{1}$ Professor Emeritus, ${ }^{2}$ Assoc. Professor, ${ }^{3}$ Asst. Professor, Baruch Institute of Coastal Ecology and Forest Science, Clemson University, PO Box 596, Georgetown, SC 29442.

\begin{abstract}
Undeveloped forested wetlands in the valleys of coastal plain rivers can play a large role in storing floodwater and attenuating river flooding. In the lower Pee Dee, Little Pee Dee, and Lynches Rivers, these wetlands played a large role in mitigating downstream flooding following Hurricane Florence. Wetland forest flood mitigation was most effective for large flows in the Great Pee Dee River, where flooding on former river terraces determined the course of overbank flow and the potential storage of floodwaters. Floodwater storage and attenuation of water level were less effective if larger flows were limited to the Little Pee Dee River. Large rains prior to Hurricane Matthew, and to a lesser extent Tropical Storm Bertha, caused the forested wetland to be a source of additional flow, although with little increase in peak stage.
\end{abstract}

\section{INTRODUCTION}

In a previous paper, we concluded that flooding in the Pee Dee River Basin due to Hurricane Florence was mitigated by processes in tidal creeks and storage within the floodplains of the Great Pee Dee, Little Pee Dee, and Lynches Rivers (Williams et al. 2019). To better understand the tidal channels, we compared flooding associated with Hurricane Matthew and Tropical Storm Bertha, in addition to Hurricane Florence. We found that tidal stagnation varied with river flow but was consistent between hurricanes, and Tropical Storm Bertha revealed a critical role of the channels connecting the Pee Dee and the Waccamaw Rivers (Williams et al. this volume). In this paper we will examine floodplain storage during these same three tropical systems. The peak flow entering the tidal system from the Pee Dee River was quite similar for each of these tropical systems despite vastly different peaks in the river's tributary to that point (Table 1). These values suggest that storage within the tributary floodplains differed greatly.

A major finding of our previous paper (Williams et al. 2019) was that significant storage in forested wetlands along the lower Lynches, Pee Dee, and Little Pee Dee floodplains reduced the peak flow of the combined Pee Dee River into the Winyah Bay estuary/tidal river system. Flood peak reduction and floodwater storage are generally regarded as a value of riparian forested wetlands (Mitsch and Gosselink 2000).
Bullock and Acreman (2003) noted that forest vegetation tends be especially effective in slowing overbank flow. However, it was also noted that specific results may depend on topography, upland soil types, and antecedent moisture conditions (Acreman and Holden 2013).

In this paper we will examine the role of floodplain forested wetlands in storage and attenuation of peak flooding following Hurricanes Florence and Matthew and Tropical Storm Bertha. Hurricane Matthew had a common coast parallel storm track and resulted in high flow in the Little Pee Dee but modest flow in the Great Pee Dee. Tropical Storm Bertha had a less common coast perpendicular storm track, resulting in large flow in the Lynches and Great Pee Dee but modest flow in the Little Pee Dee. Finally, Hurricane Florence had a unique lingering, meandering storm track that produced very large or record flow in all the tributaries. The primary focus of this paper will be on the geomorphology of the lower Pee Dee Basin and its interaction with flow in each river system. In particular, how does the topographic setting of the forested wetlands of each river impact their function on flood wave storage and attenuation?

\section{METHODS}

The role of the floodplain in flood peak storage and attenuation can be examined by the simplest form of control 
Table 1. Peak flows (cfs) of the Pee Dee River at Bucksport and the three rivers, tributary to that gauge, during the floods resultant from Hurricanes Florence and Matthew and Tropical Storm Bertha. (Numbers in parentheses after each gauge refers to locations in Figure 1.)

\begin{tabular}{lllll}
\hline Storm & $\begin{array}{l}\text { Lynches River Effingham (6) } \\
\mathbf{0 2 1 3 2 0 0 0}\end{array}$ & $\begin{array}{l}\text { Great Pee Dee River Below } \\
\text { Pee Dee (4) 02131010 }\end{array}$ & $\begin{array}{l}\text { Little Pee Dee River } \\
\text { Galivants Ferry (7) } \\
\mathbf{0 2 1 3 5 0 0 0}\end{array}$ & $\begin{array}{l}\text { Pee Dee River Bucksport (9) } \\
\mathbf{0 2 1 3 5 2 0 0}\end{array}$ \\
\hline Matthew & 9,670 & 32,000 & 59,100 & 129,000 \\
Florence & 8,630 & 139,000 & 64,500 & 137,000 \\
TS Bertha & 10,200 & 75,200 & 15,700 & 102,000 \\
\hline
\end{tabular}

volume analysis: conservation of mass (White 2016). The control volume is the floodplains between the upstream and downstream stations. Flow at the upstream station is assumed to enter storage, while flow at the downstream station is assumed to be flow from storage. As the flood moves through the control volume, flow at the upstream station initially exceeds downstream, increasing storage. As storage increases, flow at the downstream station increases until storage reaches its maximum. Flow at the downstream station begins to exceed flow at the upstream station and continues to exceed until storage has been depleted. Then, flow at both the upstream and downstream stations returns to equal. The total volume of water passing both stations should be equal at that time. Any differences in total volume represents either gain (inflow not measured) or loss (outflow not measured).
In this paper we used data collected in the same manner as our previous papers (Williams et al. 2019, this volume). Websites of stream gauges in the lower Pee Dee Basin (Figure 1, Table 2) were visited at USGS current conditions for South Carolina (USGS "Current conditions for South Carolina"). Stage and flow data were downloaded from each individual gauge website. Data were retrieved for each hurricane (Matthew, September 25-November 25, 2016; Florence, September 10-October 10, 2018; and Bertha, May 20-June $20,2020)$ to cover a period from just prior to the storm until the rivers had returned to nearly pre-storm levels. Stage data were converted to water level in the NAVD88 datum to be comparable to each other and the LiDAR land elevations retrieved from the SCDNR Data Clearing House website (SCDNR "LiDAR status by county"). At each gauge site the "Summary of Available Data" page was opened, and the

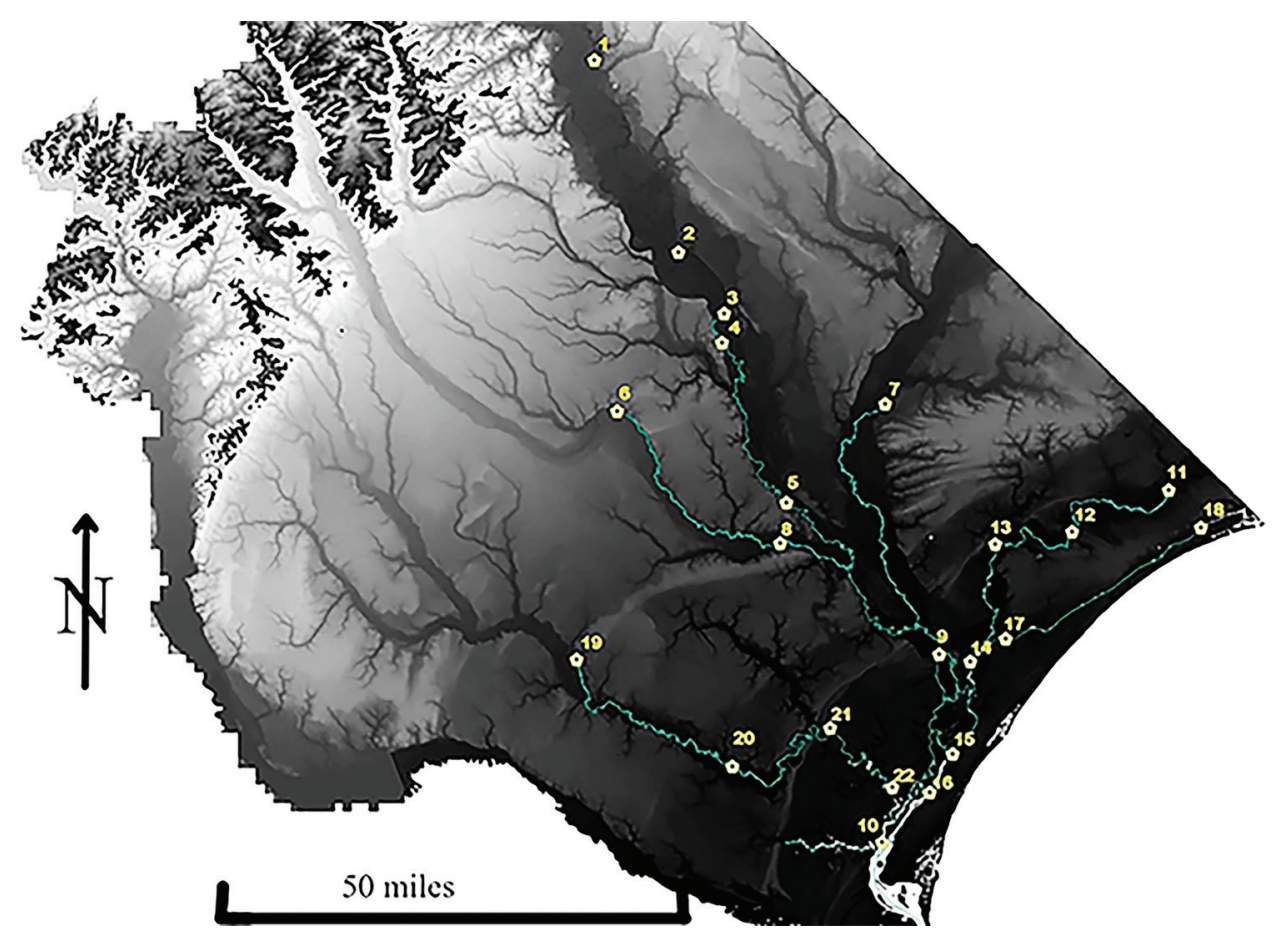

Figure 1. Topography of northeastern South Carolina based on light detection and ranging (LiDAR) data collection (SCDNR "LiDAR status by county") with representation of rivers of lower Pee Dee Basin. USGS stations listed in Table 1 are numbered on the map. Elevation is shown using a repeated grayscale where $<0$ $\mathrm{ft}$ (below sea level) is white, 1-255 ft above sea level is black (low) to white (high), and 256-512 ft above sea level is the repeated black to white shading. 
Table 2. Distribution of USGS gages in the Lower Pee Dee Basin active during at least one of the studied hurricanes. All water levels are in the NAVD88 datum. ND = no data.

\begin{tabular}{|c|c|c|c|c|c|}
\hline USGS number & Short location name & Number in Fig. 1 & $\begin{array}{l}\text { Peak WL } \\
\text { Matthew (ft) }\end{array}$ & $\begin{array}{l}\text { Peak WL } \\
\text { Florence }(\mathrm{ft})\end{array}$ & $\begin{array}{l}\text { Peak WL } \\
\text { Bertha }(\mathrm{ft})\end{array}$ \\
\hline 02130561 & Bennettsville & 1 & 82.62 & 98.27 & 88.06 \\
\hline 02130810 & Florence & 2 & ND & 61.01 & 56.15 \\
\hline 02131000 & At Pee Dee & 3 & 46.68 & 55.37 & 51.43 \\
\hline 02131010 & Below Pee Dee & 4 & 43.92 & 51.25 & 47.99 \\
\hline 335413079261000 & Pee Dee at Hwy 378 & 5 & ND & 37.33 & ND \\
\hline 02132000 & Lynches Effingham & 6 & 75.27 & 74.32 & 75.22 \\
\hline 02135000 & Little Pee Dee & 7 & 40.05 & 40.17 & 33.74 \\
\hline 335025079265600 & Lynches Johnsonville & 8 & ND & 25.98 & ND \\
\hline 02135200 & Bucksport Pee Dee & 9 & 13.68 & 16.08 & 12.34 \\
\hline 02136350 & Georgetown & 10 & ND & 4.14 & 3.9 \\
\hline 02110500 & Longs & 11 & 16.94 & 24.45 & 17.47 \\
\hline 02110550 & Above Conway & 12 & 15.77 & 19.82 & 11.98 \\
\hline 02110704 & Conway & 13 & 11.80 & 15.07 & 7.99 \\
\hline 02110802 & Bucksport Waccamaw & 14 & 7.04 & 11.41 & 6.95 \\
\hline 021108125 & Pawleys & 15 & 5.82 & 6.85 & 4.82 \\
\hline 02110815 & Hagley & 16 & 5.68 & 5.23 & 4.65 \\
\hline 02110725 & AIWW Socastee & 17 & 8.33 & 10.98 & 6.44 \\
\hline 02110815 & AIWW Little River & 18 & 7.24 & 5.88 & 5.39 \\
\hline 0213600 & Black, Kingstree & 19 & 40.48 & 34.47 & 39.17 \\
\hline 02136030 & Black, Andrews & 20 & ND & 5.34 & 9.44 \\
\hline 333250079240400 & Black, Browns Ferry & 21 & ND & 3.98 & ND \\
\hline SCGE025843 & Black, Plantersville & 22 & ND & 3.77 & ND \\
\hline
\end{tabular}

gauge datum was recorded. For some gauges this value is already in NAVD88, while in the older gauges the vertical datum was NGVD29 and the horizontal datum was NAD27. For the older gauges, the horizontal position was transposed to the NAD83 horizontal datum with an online tool (NOAA NADCON), and then the vertical datum was transposed to NAVD88 with an online tool (NOAA VERTCON). These corrections are listed in the previous papers (Williams et al. 2019, this volume). The location of each gauge is presented in Figure 1, while the USGS gauge number, a brief name, and peak water levels of each storm are listed in Table 2.

For each storm, flow rates were converted to volume as acre-feet (ac-ft) by calculating total cubic foot volume from streamflow data over either 15- or 30-minute periods between observations, converting that to ac- $\mathrm{ft}$, and summing them for each day to create an average discharge of acre-feet per day (ac-ft/d). For Hurricanes Florence and Matthew, flow for the gauges At Pee Dee (3) and Below Pee Dee (4) were recorded at 30-minute intervals. Acre-foot conversions were done for Below Pee Dee (4), Lynches Effingham (6), Little Pee Dee (7), and Bucksport Pee Dee (9) after all three storms. The data from these four gauges were then analyzed by the control volume technique for flows after each of the three hurricanes.

County LiDAR DEMs of the fourteen counties of northeastern South Carolina were downloaded from the SCDNR GIS Clearinghouse (SCDNR "LiDAR status by county"). A mosaic database was created from the individual county LiDAR scenes with Arc-GIS 10.6 (Figure 1). Maps of the Pee Dee Basin's geomorphic history (Baldwin et al. 2006) were referenced to this mosaic. Using those maps as a guide, historic terraces were interpreted for the lower Pee Dee River Basin.

Elevation of the ancient Pee Dee terraces could be related to stage values of the river. Relevant terraces were most apparent near the Below Pee Dee gauge (4). To quantify the relationship to flood volumes, a raring curve (mathematical relationship of stage to discharge) was constructed for that gauge. Since discharge generally increases with the logarithm of stage (Henderson 1966), a rating curve generally uses a logarithmic transformation of flow rate and linear values of stage height. USGS rating curves are not published online, but all observations of stage and flow are available from the "Surface Water: Field measurements" page at each gauge's 
website. These observations for the Below Pee Dee gauge (14) were downloaded and used to determine a best/least square fit of logarithmic transformed flow versus stage relationship for that site. The relevant terrace elevation was used with that relationship to estimate a flow rate that resulted in flooding of that terrace.

\section{RESULTS AND DISCUSSION}

In the previous paper (Williams et al. 2019), we used the control volume technique to estimate the role of the forested wetlands in the lower Great Pee Dee, Lynches, and Little Pee Dee Rivers following Hurricane Florence. We found that storage on the floodplain retarded the peak by five days and reduced peak flow by nearly 50\% (Williams et al. 2019). A similar analysis of the flooding following Hurricane Matthew and Tropical Storm Bertha showed dissimilar results (Figure 2 ). The large amount of storage and attenuation of the peak flow found after Florence was not repeated in the other storms. The flood following Hurricane Matthew showed that little water was stored on the floodplain, with a great deal of ungauged gain at Bucksport Pee Dee (9). Storage after Tropical Storm Bertha was intermediate between the responses after the two hurricanes. The maximum storage shown in Figure 2 was highly related to the peak flow in the Great Pee Dee River (Table 1). Maximum storage after Hurricane Florence was 1.2 million ac- $\mathrm{ft}$ and Great Pee Dee peak flow was 139,000 cfs. For Tropical Storm Bertha, comparable numbers were $580,000 \mathrm{ac}-\mathrm{ft}$ and 75,200 cfs, and for Hurricane Matthew they were $250,000 \mathrm{ac}-\mathrm{ft}$ and $32,000 \mathrm{cfs}$.
The best explanation of the widely variable behavior of floodplain storage after these storms may come from the complex geologic history of the Lower Pee Dee Basin. Northeastern South Carolina and southeastern North Carolina lie on the Cape Fear Arch, which has been rising over the last 60 to 100 million years (Cronin 1981). This rise has caused the Cape Fear and Pee Dee Rivers to each migrate southward, resulting in old river terraces on only the north side of each river (Soller 1988). Baldwin et al. (2006) compiled and summarized a history of the geomorphology of the Pee Dee valley and offshore South Carolina from over 50 years of geologic and geomorphic research in the area. Their summary included map illustrations of northeastern South Carolina that summarized important aspects of the geomorphology of the Pee Dee River. Those illustrated maps were rectified to the LiDAR mosaic created for this study and elements of 7 terraces were transferred, as well as the offshore channels, and probable river mouth location for each of those terraces (Figure 3, Table 3). In addition to the underlying topography, a map of coastal soils that have been colored to reflect soil drainage and sub-surface texture was also used (Williams and Amatya 2016). Terrace positions generally follow the information of Baldwin et al. (2006), but boundaries have been adjusted where prominent soil type or elevation data suggested a need for revision.

The oldest remnant floodplain of the Pee Dee is near the North Carolina border. It is marked by a pair of low bluffs with well-drained clay subsoils between them. This floodplain is associated with a high stand of sea level in the mid to later Pliocene, 2.4 to 1.8 million years ago, marked

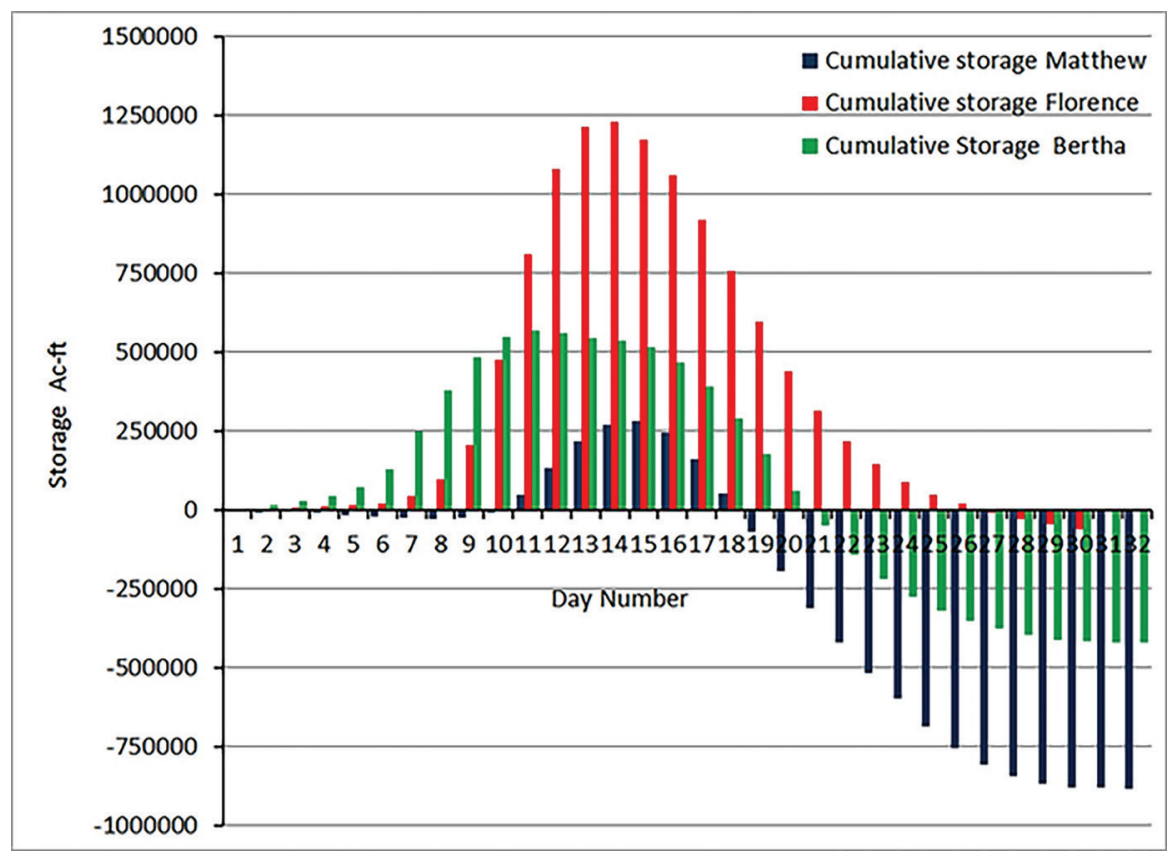

Figure 2. Cumulative storage in the lower reaches of the Lynches, Great Pee Dee, and Little Pee Dee Rivers during flooding after Hurricane Matthew, Hurricane Florence, and Tropical Storm Bertha. 


\section{Floodplain Geomorphology and Response to Hurricanes}

by point A (Figure 3). Channels in the underlying surfaces connect point A to offshore channels cut into the ocean floor (A1, 2, and 3). These channels are assumed to have been eroded after the late Pliocene high stand.

Terraces B through E span the early to late Pleistocene, from about 1.5 million to 100,000 years ago. They are successive sequences of high and low sea-level periods during that length of time. Building of the Horry Barrier sequence, high ridges to the east of gauge 7 , during the early and middle portions of the Pleistocene, diverted the river to the south. Terrace $\mathrm{C}$ is connected to a sea level that also created a significant marine terrace, the Penholoway of Cooke (1936). Terrace $\mathrm{C}$ is also evident in the Little Pee Dee, with sandy sediments. Terrace D is the most extensive of the Great Pee Dee terraces, suggesting extensive erosion during the period between the high stands at points $\mathrm{C}$ and D. Terraces $\mathrm{E}$ and $\mathrm{F}$ date from the late Pleistocene and are associated with the last major high stand of sea level, the Talbot ocean terrace of Cooke (1936). These terraces also represent the first set where a terrace associated with the high stand (E) and the terrace associated with subsequent low stand (F) are both present. No terrace could be found associated with channel $\mathrm{G}$. The only upland evidence of this outlet is a series of dunes that extend from Below Pee Dee (4) to the edge of Winyah Bay at point G. Gardner and Porter (2001) and Springer et al. (2010) suggested that a floodplain associated with channel G may have existed as little as 6,000 years ago.

There are two aspects of the geologic history of the Pee Dee River that are important to understand why storage varied with the flow of the Great Pee Dee River. First, there are no terraces on the Little Pee Dee River below point $\mathrm{C}$, and the channel from the upland $\mathrm{C}$ to the offshore CDE channel was occupied from the early to late Pleistocene, up to 800,000 years ago. During that period. sea level fluctuated from high during interglacial periods, to low during glacial periods, at least three times. During those high stands of sea level, the Little Pee Dee River may have been connected to the Great Pee Dee in the same way the present river is connected to the Waccamaw River. That is, the estuary and main tidal channel were in the Little Pee Dee valley while the Great Pee Dee entered one or multiple channels from the west. The distance from point $\mathrm{E}$ to point $\mathrm{C}$ is about 11 miles, within a few thousand feet of the length of the current Winyah Bay. That region of the Little Pee Dee valley was probably subject to strong tidal flow and tidal erosion, with the current valley fill near 5-10 ft in elevation.

The second factor is the relationship of the $\mathrm{E}$ and $\mathrm{F}$ terraces and the sand dunes deposited at the eastern edge and on the F terrace. Although the two terraces are quite similar in elevation, they differ in subsoil and surface appearance. Terrace E shows numerous meander scars and has a common clay loam or clay subsoil, Terrace F has a silt loam subsoil, and the surface shows braided rather than meandering paleochannels. A braided terrace near the present floodplain has been found on several southeastern river systems (Leigh et al. 2004), which have been dated from 17,000 to 60,000 years old. Leigh (2006) later found braiding changed to meandering between 15,000 and 16,000 years ago, with meandering

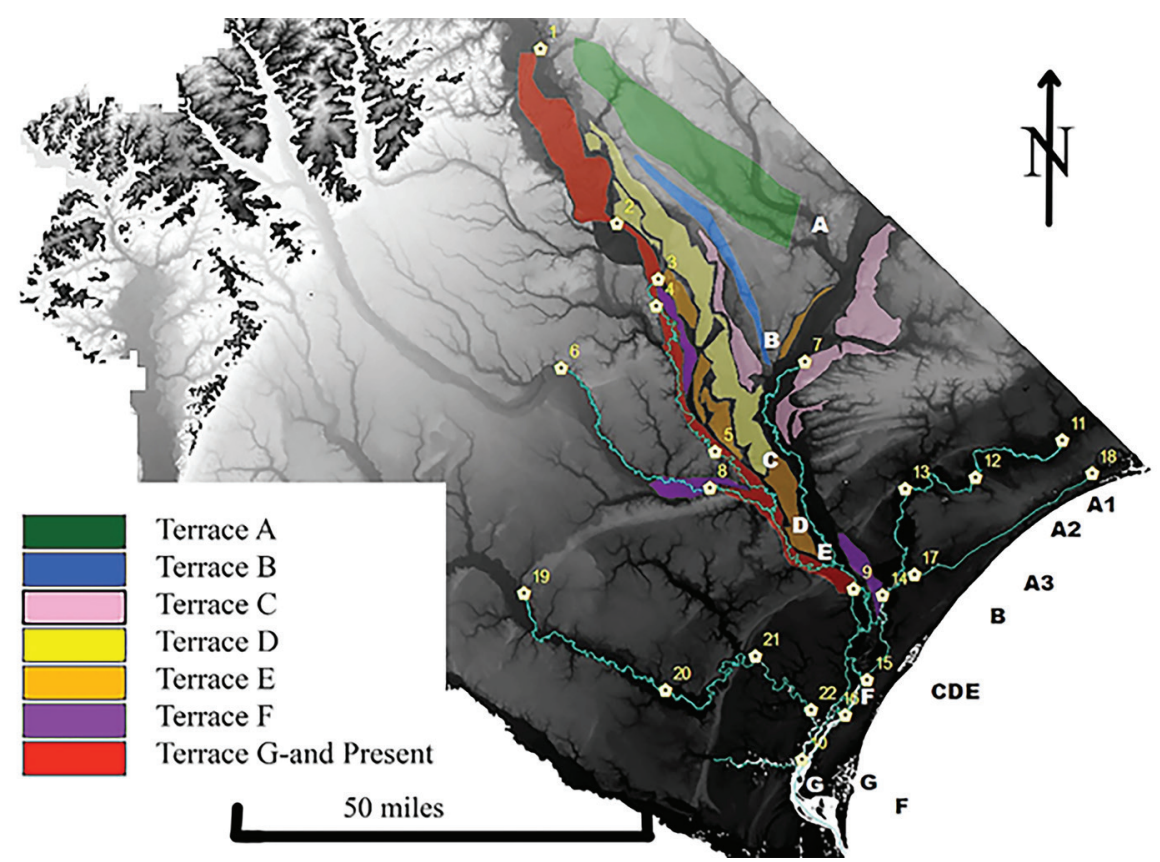

Figure 3. LiDAR DEM as in Figure 1, with information derived from geomorphic history contained in Baldwin et al. (2006). Each white letter is the approximate ocean position associated with the colored terrace of the same letter. The black letters reflect the offshore channel connected to the points that were eroded during low sea level. 
Williams, Song, Hitchcock, O'Halloran

Table 3. Elevations of the upstream and downstream ends of Pee Dee terraces mapped in Figure 4. All elevations are in feet NAVD88. No terrace can be identified with $\mathrm{G}$; it is indistinguishable from the present floodplain.

\begin{tabular}{llllllll}
\hline Terrace & A & B & C & D & E & F & G and FP \\
\hline Upstream Elevation & 130 & 115 & 87 & 62 & 40 & 37 & 37 \\
Downstream Elevation & 100 & 90 & 51 & 37 & 19 & 15 & 3 \\
Terrace Slope (ft/mile) & 0.85 & 0.81 & 1.18 & 0.54 & 0.52 & 0.46 & 0.77 \\
\hline
\end{tabular}

common since that time. The dunes along terrace $\mathrm{F}$ are also a feature common to southeastern rivers (Markewich and Markewich 1994) and are approximately contemporaneous with the braided channels. They also noted that two sets of dunes are also quite common on southeastern rivers, with an older (approximately 30,000 years) set removed from the present floodplain and a younger group (approximately 15,000 years) on the braided terrace. These younger dunes can be easily seen on LiDAR, and they border the eastern side of the present floodplain to near point $\mathrm{G}$.

The interaction of flow with the terraces of the Great Pee Dee River are demonstrated in Figures 4, 5, and 6, with the water elevations measured in Table 2 applied to cross-sections of the Great and Little Pee Dee valleys at the location of each gauge. All these gauges operated during Hurricane Florence. To estimate elevations for Hurricane Matthew and Tropical Storm Bertha, the water-level slope between Below Pee Dee (4) and Bucksport Pee Dee (9) was determined for all storms. The water-surface slope for Tropical storm Bertha was 1.3\% higher than for Hurricane Florence, while the water surface slope for Hurricane Matthew was $16.3 \%$ smaller. Given the similarity in water surface slope, the following calculation could be used to estimate stage at those gauges.

$(f g 4-f g 5) /(f g 4-f g 9)=(b g 4-b g 5) /(b g 4-b g 9)=(m g 4-m g 5) /(m g 4-m g 9)$

were solved for $b g 5$ and $m g 5$, and

$$
(f g 4-f g 8) /(f g 4-f g 9)=(b g 4-b g 8) /(b g 4-b g 9)=(m g 4-m g 8) /(m g 4-m g 9)
$$

were solved for $b g 8$ and $m g 8$. where $f g 4, f g 5, f g 8, f g 9$ were the elevation of gauges 4, 5, 8, and 9 at peak flow of Hurricane Florence, and $m$ and $b$ prefixes were elevations at peak flow of Hurricane Matthew and Tropical Storm Bertha, respectively. These estimations were used to examine water depth at crosssections of the river valley at gauge 5 and 8 in Figures 4, 5, and 6 , respectively.

At gauge 4 (Below Pee Dee), both Florence and Bertha flooded onto the E terrace, while Matthew was only high enough to flood the F terrace. At gauge 5 (Pee Dee at Hwy 378), high dunes form a continuous bank along the edge of the floodplain for a 9-mile stretch and constrain the present floodplain. These dunes either cover the F terrace, or it has been eroded by the modern river. On this cross-section, the elevation of both Florence and Bertha would imply flooding on both the $\mathrm{E}$ and $\mathrm{D}$ terraces. Without thorough modeling, it is not possible to know if or how much floodwater made its way on the E terrace from upstream, but that would have been possible during both Florence and Bertha. As we postulated previously (Williams et al. 2019), the shape of the hydrograph and the flow rate of the Lynches River indicate that gauge 8 (Lynches Johnsonville) rose by backwater from the Great Pee Dee. If that was the case, the elevation of peak flow for Bertha and Matthew here may be overestimated, since there would likely be less backwater with smaller flows of those storms.

A reasonable explanation of the connection of flow in the Great Pee Dee and the degree of storage by the forested wetlands is a variation in the quantity of water that flows over terrace $\mathrm{E}$ at the junction of the Great Pee Dee and Lynches rivers. Following Hurricane Matthew, peak flow in the Great Pee Dee was 32,000 cfs, which did not cause flooding on terrace E and thereby not into the Little Pee Dee floodplain. In contrast, the peak flow of the Great Pee Dee was 139,000 cfs following Hurricane Florence. The larger flow resulted in flooding of the E terrace near the junction of the Lynches River, leading to rapid overland flow into the Little Pee Dee floodplain. There, the Little Pee Dee floodplain is roughly $10 \mathrm{ft}$ lower than the E terrace, providing ample opportunity for storage and attenuation of flooding downstream. Given that Great Pee Dee flow after Tropical Storm Bertha was intermediate between the other two storms, the behavior of the flooding was also intermediate.

Geomorphology appears to have had a large influence on storage and attenuation of flooding after each tropical cyclone, but it does not explain the large difference in unaccounted flow found in the control volume analysisnearly 900,000 ac-ft-following Hurricane Matthew. Those results may be due to the threshold behavior of forested watersheds (Williams 2016). Forested watersheds produce little to no runoff until a critical threshold is reached. That threshold is controlled by the rather large amounts of rainfall that can be stored in forested watersheds. However, once that storage is exceeded, a large portion of incoming rainfall becomes runoff. Threshold behavior seems to be the likely reason why the forested wetland added a great deal of flow following Hurricane Matthew. Prior to Hurricane Florence, the lower Pee Dee Basin received very little rainfall during August 2018, which also experienced high transpiration loads (Figure 7). Rain in the lower Pee Dee Basin in September 2016 


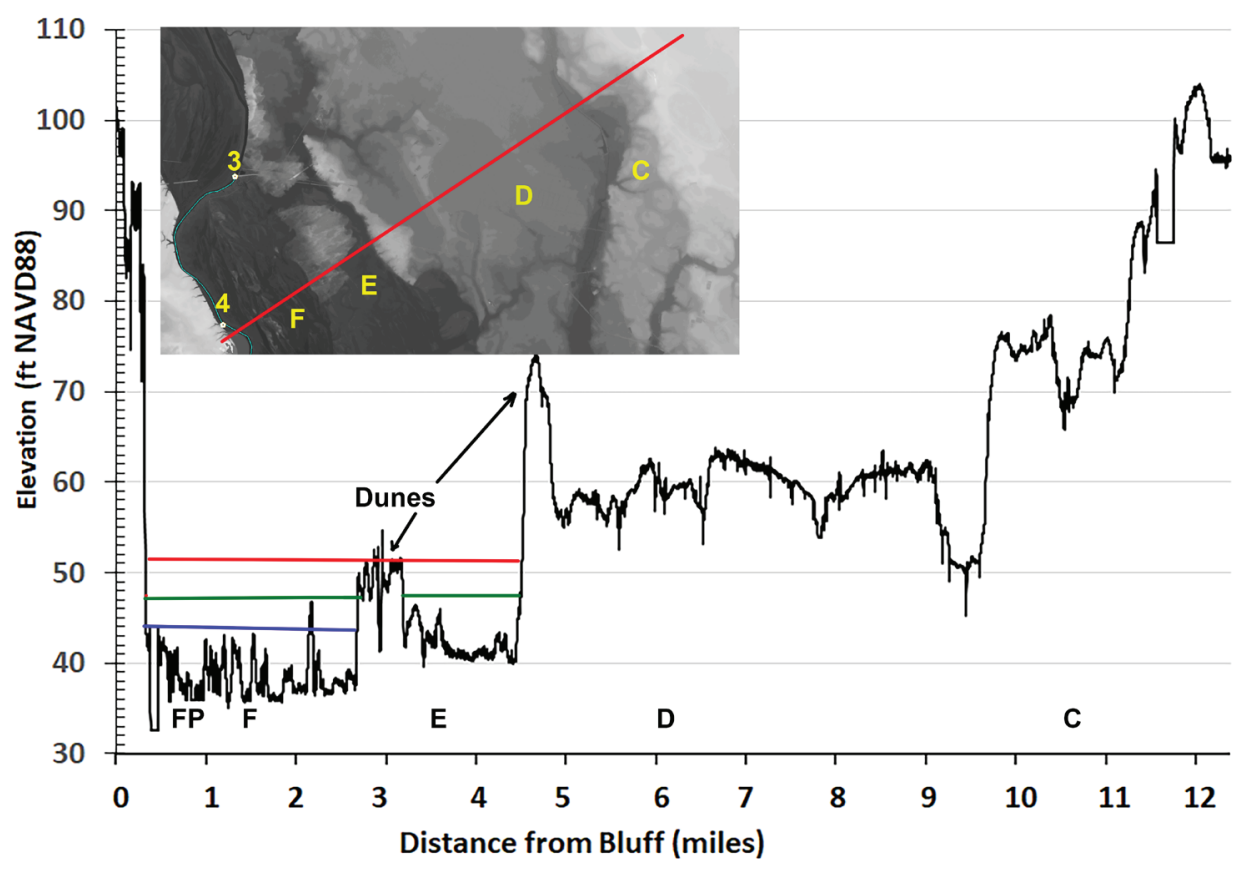

Figure 4. LiDAR Dem and cross-section of the Great Pee Dee terraces with elevation of water measured at gauge 4 (Figures 1 and 3) during Hurricane Florence (red), Tropical Storm Bertha (green), and Hurricane Matthew (blue). FP is the current floodplain and F, E, D, and $\mathrm{C}$ are locations of terraces described in the narrative.

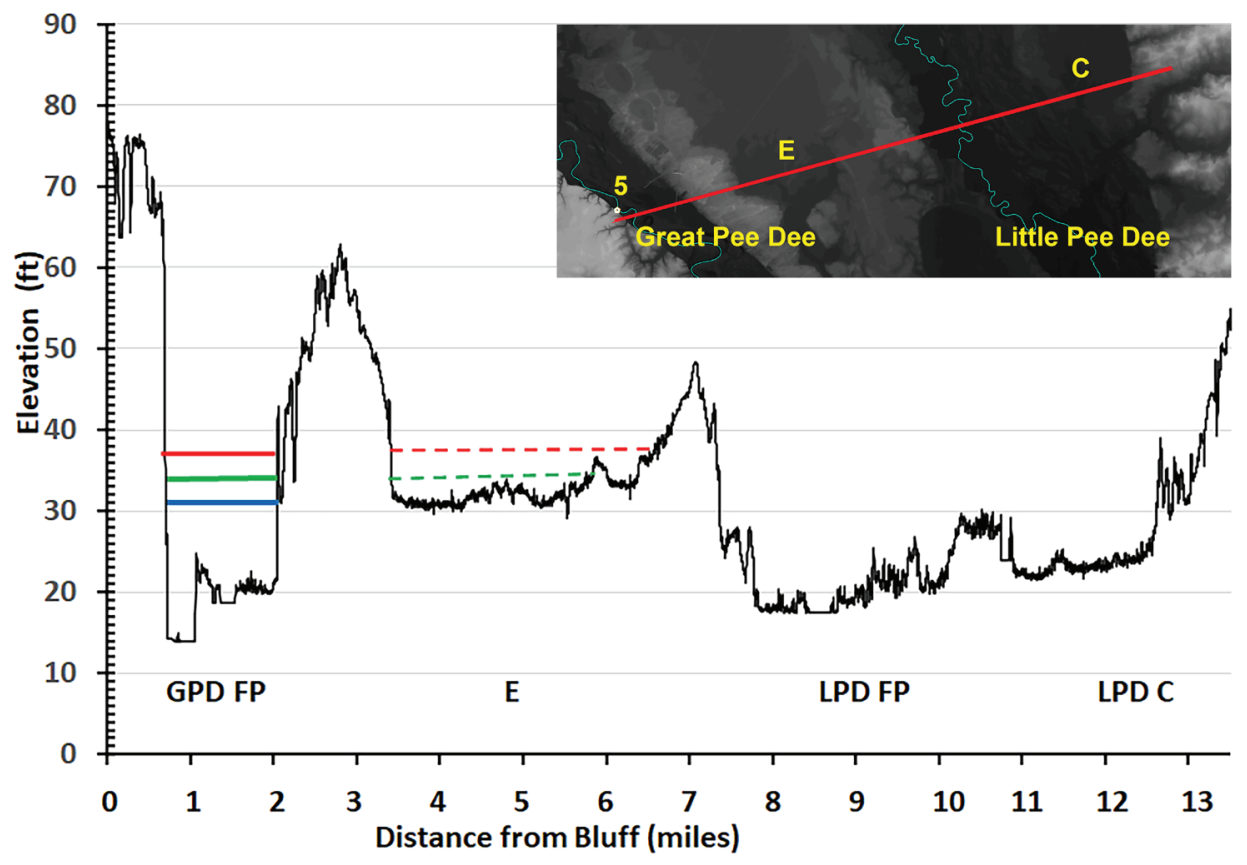

Figure 5. LiDAR Dem and cross-section of the Great Pee Dee terraces with elevation of water measured at gauge 5 (Figures 1 and 3) during Hurricane Florence (red), Tropical Storm Bertha (green), and Hurricane Matthew (blue). GFP and LPD FP are floodplains of Great and Little Pee Dee Rivers, while E and LPD $\mathrm{C}$ are terraces on those rivers described in the narrative. Dotted lines indicate uncertainty in the extent of overbank flow behind the dunes. 


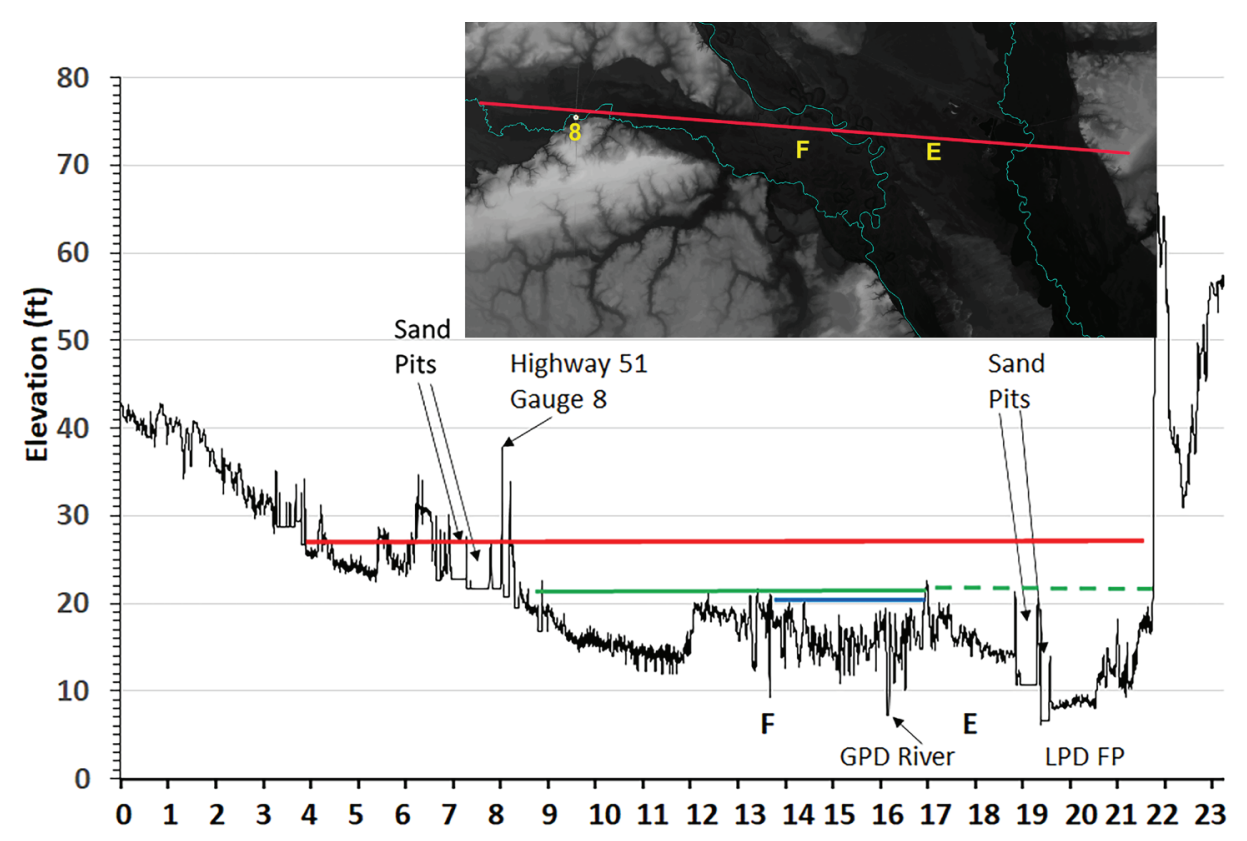

Distance downstream along Lynches, across Great Pee Dee to Little Pee Dee (miles)

Figure 6. LiDAR Dem and cross-section of the junction of Lynches and Great Pee Dee Rivers showing terrace heights with elevation of water measured at gauge 8 (Figures 1 and 3) during Hurricane Florence (red), Tropical Storm Bertha (green), and Hurricane Matthew (blue). GPD River and LPD FP are floodplains of Great and Little Pee Dee rivers, while E and F are terraces described in the narrative.

prior to Hurricane Matthew was nearly equal to the month of the hurricane. Tropical Storm Bertha occurred in late May 2020, after a relatively dry April, and had intermediate runoff. It would seem reasonable to believe that forested wetlands could have been a source of runoff following the Hurricane Matthew flood but not following Florence.

The role of forested wetlands in floodplain storage in the Winyah Bay estuary/tidal river system proved to be variable. Following Hurricane Florence, the floodplain stored over 1.2 million ac-ft of water, lowered the peak flow by nearly $40 \%$, and delayed peak flow by 5 days. However, following Matthew, there was only 250,000 ac-ft of storage, no reduction in peak flow, and a 3- to 4-day delay in peak. Tropical Storm Bertha was intermediate in both storage and peak reduction. The key difference between storms appears to be the peak flow of the Great Pee Dee River. Flows that have an elevation over $22 \mathrm{ft}$ in the area where the Great Pee Dee floodplain is no longer constrained by a dune line on the west side of the E terrace, near the junction with the Lynches River, can produce overbank flooding that can reach the floodplain of the Little Pee Dee River. The Little Pee Dee floodplain is over $5 \mathrm{ft}$ lower than E terrace at this point, providing ample room for considerable storage. At the active Below Pee Dee (4) gauge, the E terrace is about $45 \mathrm{ft}$ NAVD88. A rating curve (stage versus log flow) made from observations at the Below Pee Dee gauge (USGS "Current water Data for South Carolina") indicates that elevation is reached with a flow of about 45,000 cfs (Figure 8).

\section{SUMMARY AND RECOMMENDATIONS}

The complex geomorphic history of the Pee Dee Basin has created a situation where the behavior of the floodplains depends on two unique thresholds. Flow of the Great Pee Dee River at rates over 45,000 cfs resulted in flooding across an old terrace and utilizing a large area of available storage in the Little Pee Dee valley. For Hurricane Florence, this retarded peak discharge for 5 days and reduced the peak by nearly $50 \%$. This occurred after little antecedent rainfall in the month before Hurricane Florence. Alternatively, with Great Pee Dee flow under 45,000 cfs, floodwaters did not cross the older terrace and the peak was retarded for only 3 days. In contrast, Hurricane Matthew, with over $12^{\prime \prime}$ of antecedent rainfall, did not show a delayed peak due to floodplain storage, and the floodplains contributed a large volume of additional runoff.

This work supports the conclusions of Acreman and Holden (2013) that the role of forested wetlands in flood mitigation depends on topography and antecedent moisture, although the important topography in this case was the geomorphology of the floodplain itself. Forested wetlands should not be regarded as a cure-all for flood mitigation but should be evaluated in the context of actual flood behavior.

In the context of better understanding of flood behavior, this study was limited as a retrospective analysis of previously collected data. It suffered most from a lack of data on the 


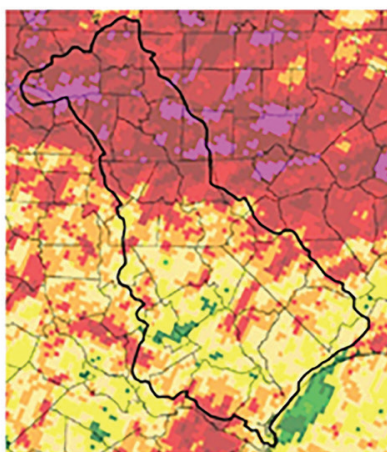

August 2018

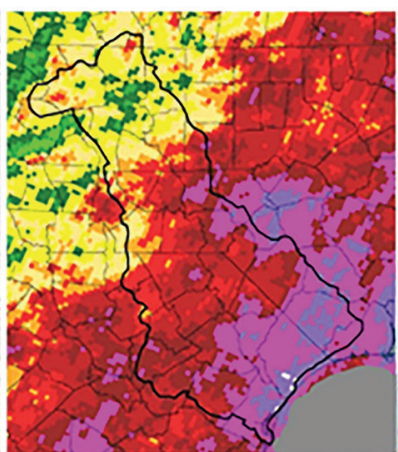

September 2016

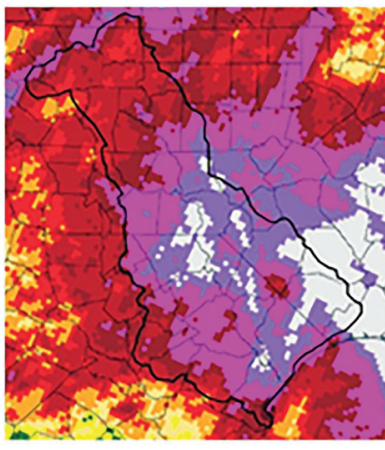

Florence

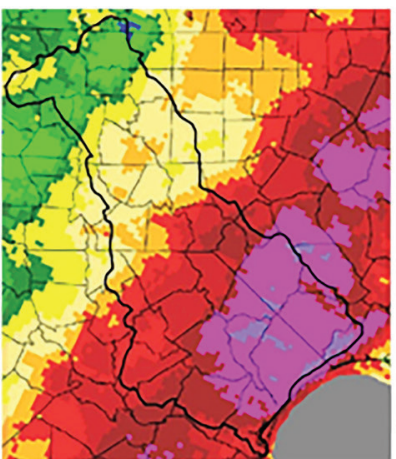

Matthew

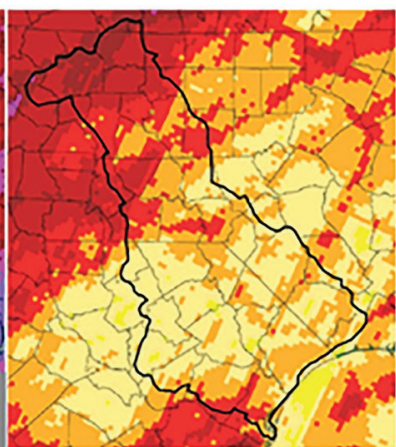

April 2020

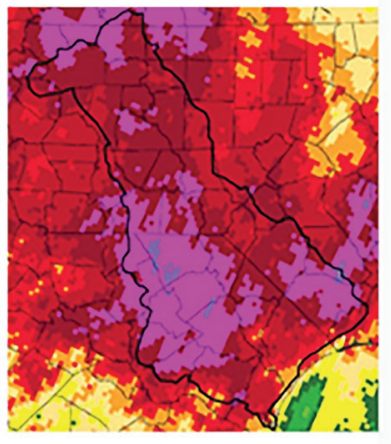

Bertha

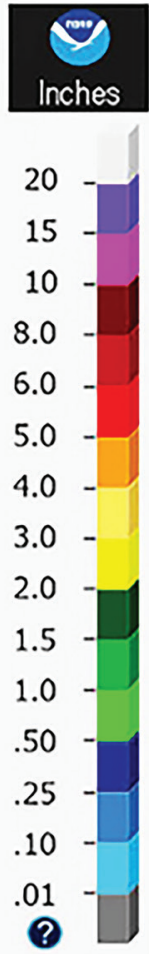

?

Figure 7. Distribution of rain across the Pee Dee Basin during the month of each hurricane and the month before that storm. Data available and distributions developed on the Advanced Hydrologic Prediction Services website (NOAA "Advanced Hydrologic Prediction Services").

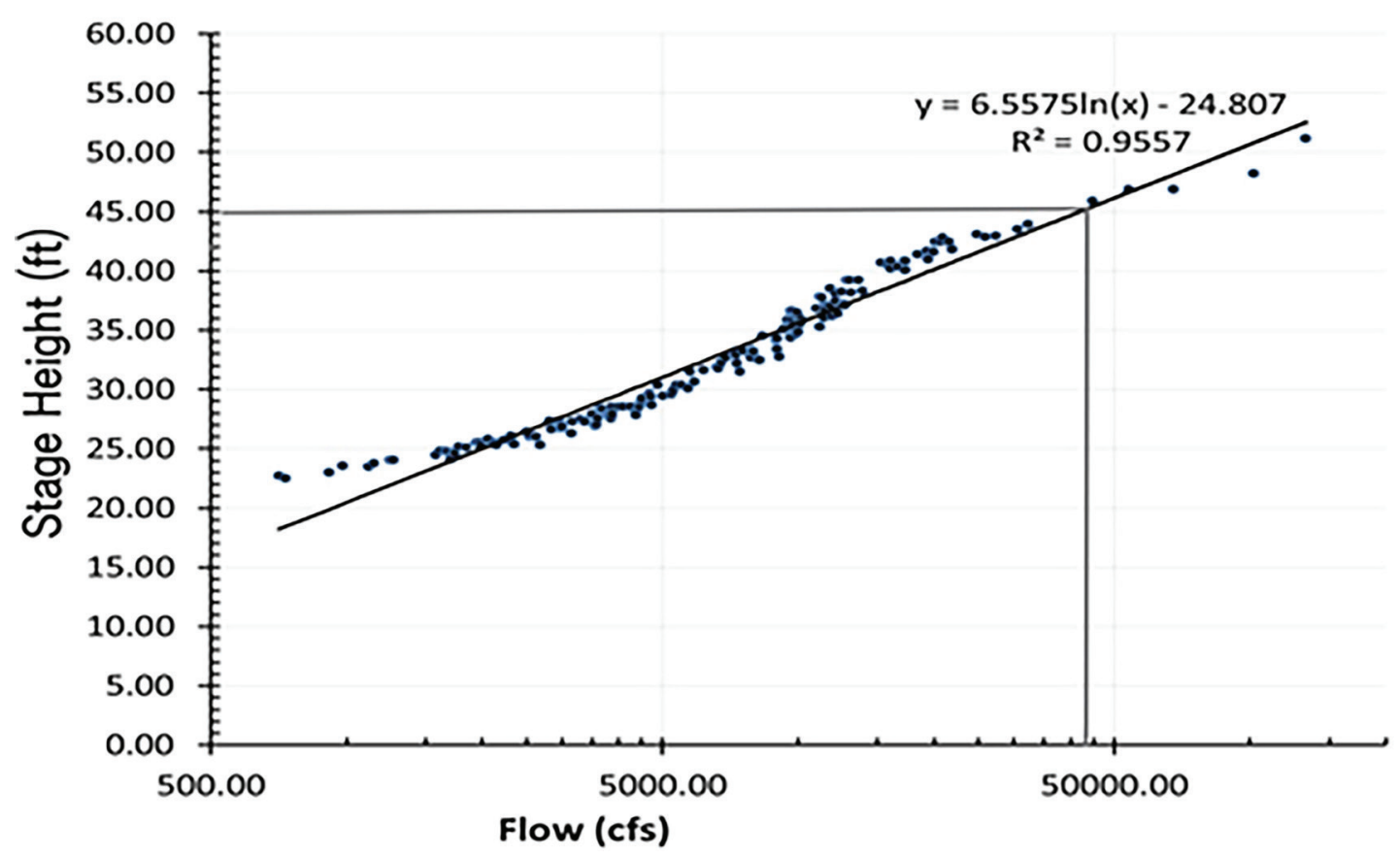

Figure 8. Rating curve for Below Pee Dee gauge (4) showing flow at the critical depth for flooding onto terrace E. 


\section{Williams, Song, Hitchcock, O'Halloran}

role of the tributary floodplain storage. Even the simplest (conservation of mass only) control volume analysis could not be done for the individual tributaries The temporary stage data from gauges 5 and 8 tributaries could be used with the flow and stage data of gauges 4 and 9 to examine water-surface slopes and estimate stage values for the other two storms. However, the addition of stage and discharge recorders at key locations on each of the tributaries just above the junctions of the Great Pee Dee and Lynches Rivers, and those with the Little Pee Dee, could be used to evaluate a controlled volume for each tributary. This would allow better predictions of flood dynamics in the future.

\section{ACKNOWLEDGMENTS}

Funds for this study were provided by the South Carolina Agricultural Station through the South Carolina Water Resources Institute. This paper is contribution number 6956 of the South Carolina Agricultural Experiment Station. The authors wish to thank Jim Hendricks for work on river centerlines used in this paper. We also wish to thank the anonymous reviewers whose comments greatly improved this manuscript.

\section{REFERENCES}

Acreman M, Holden J. 2013. How wetlands affect floods. Wetlands 33:773-786. https.//doi.10.1007/s13157-0130473-2.

Baldwin WE, Putney TR, Katuna MP, Harris MS, Gayes PT, Driscoll NW, Denny JE, Schwab WC. 2006. Migration of the Pee dee River system inferred from ancestral paleochannels underlying the South Carolina Grand Strand and Long Bay inner shelf. Geological Society of America Bulletin. 118(56):533-549.

Bullock A, Acreman M. 2003. The role of wetlands in the hydrologic cycle. Hydrology and Earth System Sciences. 7(3):358-389.

Cooke CW. 1936. Geology of the coastal plain of South Carolina. US Geological Survey Bulletin 876. Washington (DC): USGS.

Cronin TM. 1981. Rates and possible causes of neotectonic vertical crustal movements of the emerged southeastern United States Atlantic Coastal Plain: Geological Society of America Bulletin. 92(11):812-833.

Gardner LR, Porter DE. 2001. Stratigraphy and geologic history of a southeastern salt marsh basin, North Inlet, South Carolina, USA: Wetlands Ecology and Management. 9:371-385. https://doi. org/10.1023/A:1012060408387.

Henderson, FM. 1966. Open channel flow. New York: Macmillan.

Leigh DS, Srivastava P, Brook GA. 2004. Late Pleistocene braided rivers of the Atlantic Coastal Plain, USA. Quaternary Science Reviews. 23:65-84.
Leigh DS. 2006. Terminal Pleistocene braided to meandering transition in rivers of the Southeastern USA. Catena 66:155-160.

Markewich HW, Markewich W. 1994. An overview of Pleistocene and Holocene inland dunes in Georgia and the Carolinas- Morphology, distribution, age and paleoclimate. US Geological Survey Bulletin 2069. Washington (DC): USGS.

Mitsch WJ, Gosslink JG. 2000. The value of wetlands: importance of scale and landscape setting. Ecological Economics. 35:25-33.

NOAA. Advanced hydrologic prediction services. QPE quantitative precipitation estimates. https://water.weather. gov/precip.

NOAA-NGS. NADCON North American Datum Conversion to convert latitude and longitude. NOAA National Geodetic Survey. [accessed 2018 November 31]. https://beta.ngs.noaa.gov/cgi-bin/nadcon.prl.

NOAA-NGS. VERTCON Orthtometric Height Conversion. NOAA-National Geodetic Survey. [accessed 2018 November 30]. https://www.ngs.noaa.gov/cgi-bin/ VERTCON/vert_con.prl.

SCDNR. LiDAR status by County. http://www.dnr.sc.gov/ GIS/lidarstatus.html.

Soller DR. 1988. Geology and tectonic history of the lower Cape Fear River valley, southeastern North Carolina. US Geological Survey Professional Paper 1466-A. Washington (DC): USGS.

Springer, AL, Knapp, CC, Gayes, PT, Gardner, LR. 2010. The Holocene depositional history of thousand-acre marsh (Georgetown County, SC, USA) from correlation of ground penetrating radar with subsurface stratigraphy. Southeastern Geology Journal. 47(2):95-104.

USGS. USGS current water data for South Carolina. https:// waterdata.usgs.gov/sc/nwis/rt.

White FM 2016. Fluid mechanics. 8th ed. New York: McGraw Hill Education.

Williams TM. 2016. Runoff processes. In: Amatya, DM Williams, T.M, Bren L, and de Jong C, editors. Forest hydrology: processes, management, and applications, 17-31. London (UK): CABI Publishers.

Williams TM, Amatya DM. 2016. Coastal Plain Soils and geomorphology: A key to Understanding Forest Hydrology. In: Stinger CE, Krauss KW, Latimer JS, editors. Headwaters to estuaries: advances in watershed science and management. Proc. of the 5th Interagency Conference on Research in the Watersheds. Tech. Rep. SRS-211. Asheville (NC): US Department of Agriculture Forest Service, Southern Research Station. p. 14-21. Williams TM, Hitchcock D, Song B, O'Halloran T, 2019. Hurricane Florence Flooding in Georgetown County: a qualitative explanation of the interaction of estuary and tidal river. Journal of South Carolina Water Resources. 6(1):35-45. 